The Brock Review Volume 13 No. 1 (2017)

(C) Brock University

\title{
Ecocritical Echoes in William Wordsworth's Tintern Abbey
}

Elmira Bazregarzadeh

\begin{abstract}
William Wordsworth's great nature poem, Tintern Abbey (1798), sheds light on the way nature affects Wordsworth's memory and the ways his philosophical interconnection with nature enables him to attain mental growth. Through an ecocritical study of the poem, this paper examines the clash between the Yale School critics, the New Historicists, and the ecocritics. It considers how the contradictory views of the afore-mentioned critics lead to a Green reading of the poem, and it demonstrates how the internal bond between man and nature in Wordsworth's poem grants humanity peace of mind.
\end{abstract}

Key Words: Tintern Abbey, Metamorphosis, Ecocriticism, and Nature.

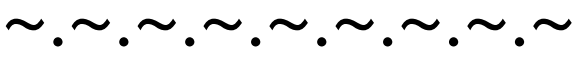

Published in 1798, Lines Composed a Few Miles above Tintern Abbey on Revisiting the

Banks of the Wye during a Tour (1798) addresses mortality, faith in nature, and familial love.

The poem is a source of environmental recognition which sheds light on the sense of belonging

to a place in an interdependent ecological community. The narrative of Tintern Abbey, according

to McKusick, "consists of the growth of the poet's mind as it evolves from an immediate

sensation of pleasure in natural objects toward a more mediated response that exults in the power

of imagination to modify and recombine the objects of perception" (25). The stress on the word

"nature" is much more than rivers, trees, rocks, etc.; Wordsworth also "means a power, a force, a

dynamic principle that animates, that molds with plastic might the physical furnishings of the

Elmira Bazregarzadeh is a PhD student in English Language and Literature at Azad University, Tabriz Branch. She graduated as the top student in English Language and Literature from Shiraz State University in 2012 and received her MA as the top student in English Language and Literature from Azarbaijan Shahid Madani University in 2014. She is an EFL instructor, and has been teaching English to young adults and adults at Iran Language Institute since 2011. She is a lecturer at Payamnour University, Marvdasht Branch, and has been teaching specialized and general courses related to English Translation since 2014. 
universe" (Poetry of Wordsworth 84). Thus, within this ecological study, I will focus on the viewpoints of the Yale School critics, the New Historicists, and the ecocritics to unravel the ecocritical echoes that have strengthened a green reading of the poem to show the effect of nature on the reciprocity of a human-nature bond.

As a key term in the literature of Romanticism, nature serves as both "a locus of imaginative energy" and "a potent source of intellectual ideas" (McKusick 28) that acts as the guiding agent for the Romantics. Considering the role of nature as a "potent source of intellectual ideas," the three stages of the poet's mental transformation in Tintern Abbey can be summarized as childhood, youth, and maturity. During the first stage, the poet's interaction with nature is similar to that of animals when there is no conscious reaction to experience. The second stage can be explained as the process of mental and bodily activities when there is direct emotional reaction to life without any thought. Unlike the previous stages, the third stage can be analyzed as a meditation process and intellectual growth followed by profound thought. Though the poet expresses himself as the "lover of the meadows and the woods" (103), his reaction to nature is not the same as before. He is in a mature state and can feel the "sad music of humanity" (91).

I argue that throughout the poem the frivolity of past memories and interconnection with nature is the savior of the poet's mind and life in the sordid days of adult life clouded with inchoate modernity. Creating a barrier between oneself and one's society is out of the question, because humans are as much the product of their social environments as their natural environments. In fact, the impact of nature on humans is so deep that it can lead people to selfexamination through their communion with natural surroundings rather than seeking an unmediated relation with nature. In this sense, nature is the agent that guides humans' souls and inspires the poet's creativity. Likewise, I claim that this poem unearths Wordsworth's concern 
about man's neglectful treatment of nature. For such ecocritics as J. Bate, J. McKusick, and K. Kroeber, the poem explains "how all parts of human nature and physical nature interactively contribute to an inclusive vitality of being multiform but not hierarchized" (qtd. in Tovey 53-4). In an effort to counter the effect of the Enlightenment models that separated humans from nature in a hierarchal tradition and brought about a gap between them whose offspring was dominion of man over nature, Wordsworth, I strongly allege, sought to originate a concordant relationship between humans and their environment based on holism and respect.

As an important figure of the Enlightenment period in Europe, Sir Francis Bacon considered science as a means of "sovereignty, dominion, and mastery of man over nature" (Keller 34). In his book, Imagining Nature (2002), Hutchings claims that Romantics questioned "the traditional Western notion that humans should exercise a hierarchical and narrowly anthropocentric ‘dominion' over the entire non-human portion of creation” (qtd. in Matthews 17). The notion of the mastery of man over nature stems from the three convictions that consider humans superior to nature: first, classical Greek humanism grants superiority to human beings over animals due to their rationality; second, the Cartesian mind/body dualism maintains that human beings, because of possessing souls, are superior to animals; and finally, the JudeoChristian notion of creation as a "Great Chain of Being," views human beings as superior to animals and plants due to the hierarchal concept that God has given man a superior position in the "Great Chain of Being" (Britto 721-2). This single poem is an effort to counteract such beliefs and goes to great lengths to emphasize that the respectful coexistence of man with nature inspires a love of self and natural surroundings that comes not only from the observation of nature, but also from emotional interaction with it. 
In fact, the Romantics suggested that there was a possibility for the emergence of the "holistic concept of nature's economy" (Hutchings, "Ecocriticism in British Romantic Studies" 178), which brings to light the point that both humans and non-humans have intrinsic value regardless of any binary opposition. If the hierarchy between man and nature is abolished, or at least questioned, the division between man and nature is shattered and a cooperative relation comes into fruition whose product, as Mahoney asserts, is "one life" as the result of a marriage between "mind and nature" which is "a rich life and full" (qtd. in Matthews 18).

Due to a clash between the New Historicists and the later critics, an ecocritical reading of Wordsworth's oeuvre came into being to the effect that "Romantic ecology," as Kroeber viewed, was an alternative for breaking the "spell of antagonistic oppositionalism" (qtd. in Yu 2) which allowed us to replace the "crude old model of Left and Right" (Bate, Romantic Ecology 3) that had influenced New Historicism. While the Green critics appreciated Wordsworth for nourishing his bond with nature and gaining spiritual and mental progress, the New Historicists blamed him for giving up on his political ideas and returning to nature or solipsism (i.e. wordsworthian or egotistical sublime). In sharp contrast to the New Historicists' tendency to historicize all the poems of Wordsworth, this paper sides with ecocritics who are engaged with the self of the Romantic poet; as McGann in The Romantic Ideology (1989) argues, Romanticism “is dominated by a Romantic Ideology, by an uncritical absorption in Romanticism's selfrepresentations" (qtd. in Yu 3).

In an effort to establish a harmonious bond between man and nature and emphasize the helpful effect of nature on man's becoming experienced, Wordsworth sought to stress the true value of nature as a result of what Beer calls, "passionate experience" (qtd. in Matthews 19). Beer's Passionate experience is accompanied by imagination and profound thought that results in 
a profound bond with nature. Kirwan believes that such a condition paves the way for humans' getting farther from the limitations of 'civilization' and going beyond "the labyrinth of history [and] customs" (ibid) and moving to the "sweet" "lore" of "nature" that affects the human "heart." If the observer tries to "watch and receive" nature open-heartedly, an understanding of the self and the ecological environments can be achieved. So, by rejecting socially constructed forms of knowledge one can reach an insightful understanding of nature which is not achievable "in the dull and endless strife" of book learning (Tintern Abbey 9).

In order to further clarify this point, I will take "Expostulation and Reply" (1798) into account to explain the power of nature in granting to humans the perception of life. In the poem, Wordsworth claims that being in tune with nature in a state of contemplation and silence can be much more informative than learning from books. The poet maintains that wisdom comes from nature, rather than from the human realm:

The eye - it cannot choose but see;

We cannot bid the ear be still;

Our bodies feel, where 'er they be, Against or with our will.

Nor less I deem that there are Powers

Which of themselves our mind impress;

That we can feed this mind of ours

In a wise passiveness.

- Then ask not wherefore, here, alone, 
Conversing as I may,

I sit upon this old grey stone,

And dream my time away. (17-24, 29-32)

The speaker acknowledges that humans cannot prevent their senses from reacting to external nature. As expressed in the poem, our organs and sensations may act "against or with our will." The emphasis on "will" intensifies the concept of the "mastery" of man over nature which serves as Wordsworth's critique of domination. The term "passive wisdom" shows nature's tendency to act upon man. In a way, the poet suggests that natural powers are as active as human powers (Matthews 21). As said by Beach, "The poet Wordsworth has been for a century the synonym of wholesomeness and piety" (346). In conjunction with such views, I hold that Wordsworth's finding consolation in nature and his emphasis on communion with nature in Tintern Abbey has been a call to awaken readers to the true value of nature in humans' lives and give them a head start to brood over the ecocritical messages inherent in each line of his poetry so that they can get at the truth of a human-nature interdependency.

As we may acknowledge, Wordsworth's contributions to Lyrical Ballads are not "nature poems" in the traditional sense in that they do not offer "precise and detailed description of natural objects" (McKusick 56). As an alternative, they reveal the possibility of a profound connection with nature, where man is affected by natural surroundings, and whose result is the formation of a harmonious relationship between man and nature. McKusick asserts, "they [the poems in Lyrical Ballads] evoke a dynamic world through the vivid sensory imagery of its beholding by an engaged participant. It is the poetry of unmediated experience, not of detached description" (ibid). The hope for an "unmediated experience" of one's natural surroundings devoid of societal mediation is the ideal of Romantic poets, which as Kirwan points out, serves 
as the prerequisite "to commune with nature" (qtd. in Matthews 22). Wordsworth's ideal has been to reconcile man with nature and ameliorate humans' ecological horizons so that they will achieve a constructive self-exploration. In fact, I would argue that for Wordsworth, the impact of nature on humans is so deep that it can lead them to self-examination through their communion with natural surroundings, rather than seeking an unmediated relation with nature.

In keeping with Ang's view, I contend that a Romantic philosophy of nature is a philosophy of the human self in which "being was built up and strengthened in communion with nature" (qtd. in Matthews 26). Hence, nature is the agent that guides humans' souls and inspires the writer's creativity. As a result, the respectful harmony of man with nature inspires a love of self and natural surroundings that comes not only from the observation of nature, but also from an emotional interaction with nature. Thanks to the stress on interaction, Wordsworth's poetry is considered, "an evocation of lived experience, rather than a specific description of the natural world" (McKusick 25). For this reason, we can infer that in Romantic philosophy and such poems as Tintern Abbey the unity between humans and their environment serves as the director of imagination and creativity so much so that nature is viewed as the power that controls life on earth and the life of the poet's mind.

Humans' readiness to receive nature results in a mediated relation between man and nature owing to wordsworthian poetic conventions. As Bowra declares, nature "has much to give, if [humans] be only ready to receive it" (qtd. in Matthews 33). Tintern Abbey unlocks the wordsworthian view of human-nature attachment. McKusick refers to the opening lines of the poem as an instance of Wordsworth's emphasis on the "peaceful coexistence of human habitation and wildness in the same place" (67):

... Once again I see 
These hedge-rows, hardly hedge-rows, little lines

Of sportive wood run wild: these pastoral farms,

Green to the very door ... (14-17)

Though the poem reveals a human-nature coexistence, the speaker contemplates the way in which humanity and nature are "simultaneously connected and divided" (Tovey 57). Toward the middle of the poem, Wordsworth discusses how the contemplation of nature brings a recognition of "The still, sad music of humanity" (91) — an observation that the "pleasant thoughts" of nature "Bring sad thoughts to the mind" (3-4) in "Lines Written in Early Spring" (1798). For Wordsworth, nature provides a contemplation of the state of mankind as well as a "respite" (Tovey 57) from "The dreary intercourse of daily life":

...'tis her privilege,

Through all the years of this our life, to lead

From joy to joy: for she can so inform

The mind that is within us, so impress

With quietness and beauty, and so feed

With lofty thoughts, that neither evil tongues,

Rash judgments, nor the sneers of the selfish men,

Nor greeting where no kindness is, nor all

The dreary intercourse of daily life,

Shall e'er prevail against us, or disturb

Our cheerful faith that all which we behold

Is full of blessings. (Tintern Abbey 123-34) 
Nature's role —as a "guide," "nurse," and "guardian" — changes over time as the poet gains maturity. In his "boyish days" (73), when he first visited the Wye Valley, nature "was all in all" (76) to Wordsworth. But, the poet says, “... That time is past, / And all its aching joys are no more" (84-5). As a result of his historical experience, which may be considered as an allusion to Wordsworth's retreat from his political stance, the poet has learned "To look on nature, not as in the hour / Of thoughtless youth, but hearing oftentimes / The still, sad music of humanity" (8991), which leads him to feel, “A presence that disturbs me with the joy / Of elevated thoughts; a sense sublime ..." (94-5). Throughout these lines we clearly see a prevailing sense of belonging to nature, where it (nature) is presented as the crucial stimulus that lightens man's path to selfrecognition through his reliance on the natural environment.

I believe that Wordsworth describes this "presence" as something that is "far more deeply interfused," and which can be seen everywhere, even in the mind of man. Wordsworth's emphasis on the existence of this profound presence in the mind of man proves the fact that man and nature are connected in the experience of a "sense of sublime." After explaining this sublime sense, Wordsworth mentions that although he could not view nature with sensuous joy, as he did in his childhood, he is "...still / A lover of the meadows and the woods, / And mountains. .." (103-04) and all the natural elements, because nature is the facilitator of an interconnection between man and a "sense sublime." His being "still" a lover of nature is an important point here, since nature is both a source of pleasure for the poet and a mirror that feeds the poet's imagination and reflects past memories and elevated thoughts.

Wordsworth was a poet whose poems stressed human ecology and humanity’s connection with nature, because he believed an understanding of nature teaches man an understanding of suffering and humanity, which serves as a means of lessening the "burthen of 
the mystery" (38) and making endurable "...the heavy and the weary weight / Of all this unintelligible world" (39-40). Durrant holds that, as an ecocritical poem, Tintern Abbey is "a landscape poem in the eighteenth century tradition" (qtd. in Britto 722). Landscape is the symbol of nature and environment, and Durrant's emphasis on the "landscape poem" showcases the concepts of ecopoetry and human-nature connectivity. Besides, it is also ecopoetry since it is "not a description of dwelling with the earth, not a disengaged thinking about it, but an experiencing of it" (Bate, Song of the Earth 42).

I agree that Wordsworth's main argument in Tintern Abbey is to reveal to the reader "a poem of emancipation and enlightenment, discovering and celebrating the harmony-indeed, unity_of man and nature" (Christie 72). Wordsworth's return to nature in Tintern Abbey is, in fact, a "therapeutic transition to the country" that represents "the cause, the condition, and the symbol of salvation" (ibid 72-3). The rudiments of Tintern Abbey, which were the products of men's hands, add much to the beauty of the picturesque landscape. However, from an ecocritical perspective, the ruin can be discussed as "a metaphor that refers to culture (that which is manmade), symbolizing the human domination over nature which results in the destruction of nature" (Britto 722). In contrast, I assert that the inhabitants of a house are the ones who grant meaning to life in that house. Therefore, when men feel superior to nature and destroys it, nature hits back and the result is what we see in Tintern Abbey, which is devoid of the human race (ibid 722-3). Conversely, if human beings understand the true value of peace in nature, it will provide them with a harmonious life. Wordsworth's withdrawal to nature and the ruins of Tintern Abbey after a considerable amount of time, in effect, is an effort to renew the concordant human-nature pact. Newman (2005), in Our Common Dwelling, explains that Wordsworth's deep interaction 
with nature enabled him "to feel 'the purer and nobler sentiments of the heart' together with the common people" and due to this he was reputed to be "a poet of liberty" (80).

One can also analyze this poem as an instance of philosophical and mental transition in the poet in which we see the wordsworthian "strategy of displacement." Displacement can be summarized as the "characteristic way of evading deeply significant political events and social realities, taking refuge instead in the cheap comforts of the romantic ideology of natural supernaturalism" (ibid 74). However, I claim that Wordsworth's taking refuge in nature was a feather in his cap and due to which he is called "the Prophet of nature" toady (ibid 71).

Some New Historicist critics, like McGann, maintain that during the "five years" mentioned at the beginning of the poem, Wordsworth "lost the world merely to gain his own immortal soul" (qtd. in Yu 139). He accuses Wordsworth of what Keats calls "egotistical sublime" (qtd. in Ramazani 328) and holds that nature is only a means to lead Wordsworth to that end. In opposition to this perspective, Simpson in Wordsworth's Historical Imagination (1987), avers that it is "most productive" to "regard the Wordsworthian subjectivity as a medium ...that was, by virtue of its openness to the energies of language and experience, extraordinarily articulate about the pressures and tensions that we may with hindsight regard as central to the culture at large" (qtd. in Yu 140).

What I would argue is that critics such as Bloom view the ruins of the abbey as a facilitator between the poet and his mind that enabled Wordsworth to reach reciprocity between his mind and the external world. One would be in debt to Wordsworth for just reading Tintern Abbey on the surface and jumping to conclusions by accusing him of the oft-quoted phrase “egotistical sublime;" for it requires a sharp mind and quick understanding to uncover what lies beneath the surface of the poem. In one such reading, Bloom summarizes the theme of Tintern 
Abbey as, "the nature of the poet's imagination and [...] imagination's relation to external nature" (qtd. in Ho 1).

In an effort to back Wordsworth, Bate, in The Song of the Earth (2000) contends that New Historicism's “potential for wider political use [...] outside the academy” is very limited, whereas Romantic ecology serves much better to "politicize Romanticism [...] in a way that speaks to our present discontents" (8). In Bate's reading, Tintern Abbey celebrates "a cottageeconomy which does not 'disturb' the ecosystem;" Wordsworth's well-known "pantheism” is defined as the view that "the whole earth is a single vast, living, breathing ecosystem" (146). I share this new angle of vision, having recourse to contemporary ecological discourse that emphasizes "regional specificity" in Wordsworth's nature poems in order to claim that Wordsworth's patriotism is rooted "in a tradition of local defense of poetry" rather than being “knee-jerk jingoism” (Song of the Earth 219, 215). Wordsworth's “critical regionalism,” Bate tries to convince us, is opposed to a "Napoleonic, expansionist" imperialism "with an investment in the denigration and even extinction of other countries" (ibid 225).

Bate's reading of Wordsworth's Tintern Abbey is double-edged; on the one hand, he tries to save the Wordsworth of the Yale School and New Historicist critics and on the other, affirms Wordsworth's position as an "ecopoet" by "linking his linguistic style to an environmental ethic" (Yu 146) in the hope of focusing on the literary value of the poem in contrast to the aesthetic one. In Bate's view, the poem serves as a critique of the picturesque tradition popularized by Gilpin which shows an anthropocentric inclination towards nature and the abbey. Bate adds that Wordsworth's "pursuing of the picturesque" reveals the Cartesian division of the mind from the body (Song of the Earth 141). Thus, the absence of the abbey from the poem is explained as a refusal to accept the "picturesque assumption that "artificial" features such as ruins [...]may be 
classed as part of nature (ibid 144). Bate, furthermore, focuses on the "...wreaths of smoke / Sent up, in silence, from among the trees" (17-18) and renders a Green reading: as an ecopoet, Wordsworth's "feeling of connectedness leads him to suppose that it might not come from the Cartesian ironwork observed by Gilpin but from the fires of "vagrant dwellers in the houseless woods," "that is gypsies as wise practitioners of "sustainable productivity [...] who know the moment when they have taken enough from a particular spot of earth and must therefore move on" (Song of the Earth 146).

As mentioned earlier, there has always been a clash between various critics about the Romantics' relation with nature and their views about it. Before coming into fruition as the Green movement (i.e. ecocriticism), the Yale School critics maintained that Wordsworth used nature to transcend his mind and imagination. The New Historicists, as Bate asserts, stressed that Wordsworth valued poetic imagination in order to do away with history and society (Romantic Ecology 8). For McGann, all the social and political issues of the time are elided in Tintern Abbey which becomes the descriptions of the natural landscape so that, by the end of the poem, "the mind has triumphed over its time": Consequently, the poem concludes in what appears to be an immense gain, but what is in reality the deepest and most piteous loss. Between 1793 and 1798 Wordsworth lost the world only to gain his immortal soul" (qtd. in Noble 74). Contrary to McGann, Abrams' Natural Supernaturalism (1971) begins and ends with readings of Wordsworth, who is deemed as the exemplary Romantic poet whose writings contain the basic tenets of Romanticism. He claims that by "consummating a holy marriage with the external universe," Wordsworth creates "a quotidian and recurrent miracle, a new world which is the equivalent of the paradise" (28). Similarly, in Romantic Ecology, Bate (1991) buttresses a return to Wordsworth's nature: "The time is now right to allow Wordsworth to become once more what 
he imagined himself to be, what Shelley called him, and what he was to the Victorians: 'Poet of nature' "(9). Due to such foundational studies as Bate's, Romantic Ecocriticism has flourished. Undoubtedly and more than any other literary movement, Romanticism provides a logical basis for environmental studies due to its association with the natural world.

Many poems of Wordsworth's, besides the one which was the main subject of this paper, invoke different aspects of ecocritical studies. Poems like Tintern Abbey are pregnant with ecocritical messages and are praised in an environmental mode in that they "conform to" the ecocritical code: "a code that focuses upon problems and solutions" (Noble 78). Taken seriously, the poems of Wordsworth have a lot to offer, if only readers try not to read them solely for pleasure. The "profound yearning for transcendent unity" is a "vital element" in the poetry of Wordsworth (Heffernan 605). In the poem, Tintern Abbey, Wordsworth described the unifying power of nature as:

A motion and spirit, that impels

All thinking things, all objects of all thought, And rolls through all things ... (100-02)

Byrd, in "Metamorphosis and Tintern Abbey: Two Notes" (1983), summarizes this poem in one word, "metamorphosis," which he clarifies as "the spiritualization of nature, the perception in nature of a transcendent life that the poet can share" (29). Bloom pictures Wordsworth's poems as "scaffolding for a more imaginative vision, and not ends in themselves" (qtd. in Lipman 1). Likewise, he believes that Romantic poets use a "map of the mind," and this "map can be put to a saving use" (ibid). If we are to link up Bloom's "map of the mind" with Wordsworth's Tintern Abbey, we reach the point that being conscious of one's self and having awareness about one's identity, especially in relation to the external world, is the poet's main 
contention in the poem (ibid). Moreover, my impression is that throughout the poem we witness the reciprocity of human mind and memory with nature which ends in the poet's meditative selfreflection and self-analysis.

Put simply, I conclude that Tintern Abbey can be taken into account as one of Wordsworth's landmarks which can teach readers that it is only via seclusion that we can learn how to connect with each other, planting within the human heart the hope of remembering what one once was through one's concordant relation with the spiritual power of nature. This notion verifies that this ecological approach (i.e. Ecocriticism), "analyses and promotes works of art which raise moral questions about human attractions with nature, while also motivating audience to live within a limit that will be binding over generations" (Gomides, qtd. in Farooq and Chandra 114).

To conclude this discussion, I have made every effort, as the chief objective of this short research paper, to prove that it is through considering Wordsworth's Tintern Abbey on its own merits that we can deduce that Wordsworth was, undeniably, a poet who was truly ahead of his time and sought to draw man back to integration with nature which is the unifying agent that hooks up man and his neighboring environments. His memorable attempt was to make it perfectly clear that man "is neither master nor slave to it [nature], but simply one part of an intricate system" (Klue 1). Despite the existing gaps in recent studies, I have striven to pinpoint that Wordsworth was a unique Romantic poet who put on view the inner soul of nature as well as the external charm of it. Time and again, we have noticed Wordsworth's fame as a worshiper of nature. Subsequently, his love of nature has made him the forerunner of the humanistic approach and guaranteed him the first and foremost place in the literature of Romanticism and the ecological studies. 
Since the emergence of Ecocriticism, the poem has yielded itself to the icons of ecocritical studies where we can see the vivid role of nature as the catalyst for the advent of a peaceful bond between human beings and nature whose product is enforcing the human society to think of the importance of nature for human survival. Also, it intensifies the notion that any act against nature yields the destruction of the humanity at large. Careful analyses of such points and poems of Wordsworth highlight his chief role as a true poet of nature, who originated a Green movement long before the rise of Ecocriticism. Through this ecological study, I sought to prove that Wordsworth was not a self-centered poet; rather, he used nature as a source of elevation of his mind and soul. As stated by D. Church, "Wordsworth was first and foremost a philosophical thinker, a man whose intention and purpose it was to think out for himself, faithfully and seriously, the questions concerning man and nature and human life" (qtd. in Bradley 90-1). I speculate that Wordsworth's role in awakening human beings to the value of natural surroundings has been of key value to many critics who share the standpoint that "he [Wordsworth] saw the cloud of human destiny, and he did not avert his eyes from it" (ibid 86).

In fact, Wordsworth's vision in the poem is "spiritual and natural" (Hogdson 374) which is similar to the developmental process of a "single mental or spiritual experience from sensation to thought" (ibid 378). Wordsworth's bucolic tendencies are a call for "locality and local loyalty [...] decrying the depersonalized life of the people in industrialized cities" (Pite, "How Green Were the Romantics" 366). L. and S. Linchman in "What We Owe the Romantics" (2007) further explain this conviction as, "Wordsworth and his contemporaries preferred rustic settings not so much because they were anti-modern, but because they sensed that the life-world was more intact there..." (350). 


\section{Works Cited}

Abrams, M. H., Natural Supernaturalism: Tradition and Revolution in Romantic Literature. New York: Norton, 1971. Print.

Ang, Susan. The Widening World of Children's Literature. New York: St. Martin's, 2000.

Bate, Jonathan. The Song of the Earth. London: Picador, 2000. Print.

---. Romantic Ecology: Wordsworth and the Environmental Tradition. London: Routledge, 1991. Print.

Beach, Joseph Warren. "Expostulation and Reply.” PMLA 40.2 (1925): 346-61. JSTOR. Web.25 July 2013. Print.

Beer, John. Wordsworth and the Human Heart. New York: Columbia UP, 1978.

Bloom, Harold. The Visionary Company. New York: Cornell UP, 1971.

Bowra, Maurice. The Romantic Imagination. Oxford: Oxford UP, 1950.

Bradley, A. C. Oxford Lectures on Poetry. New York: Saint Martin's P, 1965. Print.

Britto, John M. “An Ecocritical Reading of William Wordsworth's 'Tintern Abbey."” Academic Research International 2.1(2012): 720-5. Web. 7 Jan. 2013. <http://www.savap.org.pk/journals/ARInt./Vol.2(1)/2012(2.1-71).pdf>

Byrd, Max. "Metamorphosis and Tintern Abbey: Two Notes." Modern Philology 81.1(1983):24-37. JSTOR. Web. 5 Sep. 2013. Print.

Christie, William. “Wordsworth's Tintern Abbey: Inspiration or Aspiration?” Sydney Studies in English 15(1989-1990): 72-105. Web. 7 July 2013. Print.

Durrant, Geoffrey. Wordsworth and the Great System: A Study of the Wordsworth's Poetic Universe. London: Cambridge UP, 1970. 
Farooq, M. A. Afzal and N. D. R. Chandra. "Ecocriticism: Relevance of William Wordsworth's

'Tintern Abbey' and 'The World is too Much with Us.'” Journal of Literature, Culture, and Media Series IV. 7 \& 8(Jan.-Dec. 2012). 112-123. Print.

Gomides, Camilo. "Putting New Definition of Ecocriticism to the Test: The Case of the Burning Season, a Film (mal) Adaptation.” ISLE 13.1:(2006). 13-23.

Heffernan, James. A. W. "Wordsworth on the Sublime: The Quest for Interfusion." Studies in English Literature, 1500-19007.4(1967): 605-15. JSTOR.Web. 8 May 2013. Print.

Ho, Yun-chuan. “Wordsworth's Ecological Concepts.” MA thesis. National Sun Yat-Sen U, 2002. Print.

Hodgson, John A. "Wordsworth's Dialectical Transcendentalism, 1798: 'Tintern Abbey.'” Criticism 18.4 (1976): 367-80. JSTOR. Web. 1 Sep. 2013. Print.

Hutchings, Kevin. "Ecocriticism in British Romantic Studies.” Literature Compass 4.1(2007): 172-202. Web. 5 Oct. 2012. Print.

---. Imagining Nature: Blake’s Environmental Poetics. Montreal: McGill's Queen UP, 2002.

Keller, Evelyn Fox. Reflections on Gender and Science. New Haven: Yale UP, 1985. Print.

Kirwan, James. "Vicarious Edification: Radcliffe and the Sublime." The Greening of Literary Scholarship: Literature, Thoreau, and the Environment. Ed. Steven Rosendale. Iowa City: U of Iowa P, 2002. 224-45.

Klue, Rachel A. Man's Return to Nature. Athens: University of Georgia Press, 2008.

Kroeber, Karl. Ecological Literary Criticism: Romantic Imagining and the Biology of the Mind. New York: Columbia UP, 1994.

Linchman, Lewis P., and Sandra K. Linchman. "What We Owe the Romantics." Environmental Values 16.3(2007): 333-54. JSTOR. Web. 4 Sep. 2013. Print. 
Lipman, Rachel. “'Tintern Abbey’: Reflections on Maturation and Mortality.” Web. 5 July. 2013. 〈http://udel.edu/ rlipman/lipman_eportfolio/showcase/tinternabbey.pdf>

Mahoney, John L. William Wordsworth: A Poetic Life. New York: Fordham UP, 1997.

Matthews, Charity. Green Romanticism and Anna Jameson's Feminist Ecocriticism. Diss. U of Northern British Colombia, 2008. Canada: Library and Archives Canada, 2008. Print.

McGann, Jerome. The Romantic Ideology: A Critical Investigation. Chicago: Chicago UP, 1989.

McKusick, James C. Green Writing: Romanticism and Ecology. New York: St. Martin's P, 2000. Print.

Newman, Lance. Our Common Dwelling: Henry Thoreau, Transcendentalism, and the Class Politics of Nature. New York: Palgrave Macmillan, 2005. Print.

Noble, Nicole Shalon. “Uncommon Ecology: Reading the Romantic Iokos.” Diss. Western Ontario U, 2013. Print.

Pite, Ralph. "How Green Were the Romantics." Studies in Romanticism 35.3 (1996): 357-73. JSTOR. Web. 23 May 2013. Print.

Poetry of Wordsworth. New York: Monarch P, 1965. Print.

Ramazani, Abolfazl. John Keats: From Oblivion to Rise to Worldwide Renown, 1817-1895. Tabriz: U of Tabriz P, 2011. Print.

Simpson, David. Wordsworth's Historical Imagination: The Poetry of Displacement. New York: Methuen, 1987.

Tovey, Paige Elaine. Countless Cross-Fertilizations: Gary Snyder as a Post Romantic Poet. PhD thesis, Durham U. 2011. Available at Durham E-Theses Online: http://etheses.dur.ac.uk/672/. Print. 
Wordsworth, William. “Lines Composed a Few Miles Above Tintern Abbey.” The Norton Anthology of English Literature. The Major Authors. Gen. ed. M. H. Abrams. $7^{\text {th }}$ ed. New York: Norton, 2006. 1453-64. Print.

---. "Expostulation and Reply." The Norton Anthology of English Literature. The Major Authors.

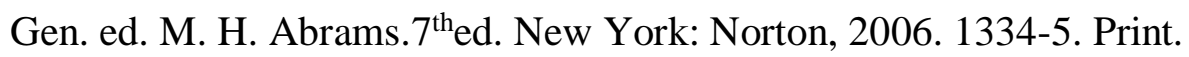

Yu, Eric K. W. "Wordsworth Studies and the Ethics of Criticism: The "Tintern Abbey" Debate Revisited." Concentric: Literary and Cultural Studies 30.2(2004): 129-54.Web. 5 Aug. 2013. <http://www.concentricliterature.url.tw/issues/The\%20Comic/6.pdf>. 